\title{
Transformacja form korytowych na przykładzie aluwiów piaskodennych rzek roztokowych środkowego vistulianu w Kotlinie Toruńskiej
}

\author{
Transformation river channel macroforms: a case study of Weichselian sand-bed braided \\ river sediments in the Toruń Basin
}

\author{
Piotr Weckwerth \\ Katedra Geomorfologii i Paleogeografii Czwartorzędu, Uniwersytet Mikołaja Kopernika, Toruń, pweck@umk.pl
}

Zarys treści: Wyniki badań sedymentologicznych prowadzonych w północnej części Kotliny Toruńskiej pozwoliły na rozpoznanie zmian architektury środowiska sedymentacji korytowej piaskodennych rzek roztokowych. Rzeki te funkcjonowały w czasie środkowego vistulianu, a ich osady należą do górnego ogniwa formacji z Zielonczyna. Ewolucja sedymentacji fluwialnej następowała w dwóch fazach, którym odpowiadają odmienne formy korytowe. W pierwszej fazie dno koryta roztokowego zdominowane było przez pojedyncze odsypy poprzeczne, zaś w drugiej doszło do rozwoju złożonych odsypów śródkorytowych w wyniku łączenia się odsypów pojedynczych. Główną przyczyną transformacji morfologii koryta rzeki była zmiana reżimu rzek z niwalnego na proglacjalny w czasie awansu czoła lądolodu w stadiale głównym zlodowacenia wisły oraz rozwój systemu pradolinnego. Transformacja morfologii koryt skutkowała także wzrostem tempa agradacji ich osadów.

Słowa kluczowe: piaskodenna rzeka roztokowa, odsypy proste i złożone, pradolina, zlodowacenie wisły

Abstract: The results of sedimentological research documented changes of architectural elements of fluvial sedimentary environment of sand-bed braided rivers in the Torun Basin. These rivers existed at the middle Weichselian and their deposits belong to the upper member of Zielonczyn Formation. The evolution of fluvial sedimentation took place in the two phases, which correspond to different channel macroforms. The braided river bed was dominated by a unit bars during the first phase, while in the second phase were evolved compound mid-channel bars as a result of the amalgamation of unit bars. The main causes of the transformation of river channel morphology in the area of the Torun Basin during the Weichselian glaciation included changes in river regime from nival to proglacial and development of ice-marginal valley. Transformation of channel morphology resulted in an increase in the aggradation rate.

Key words: sand-bed braided river, unit and compound bars, pradolina, Weichselian Glaciation

\section{Wstęp}

Zmiany warunków klimatycznych, jakie miały miejsce w czasie zlodowacenia wisły, wpływały na intensywność procesów agradacji osadów lub erozji rzecznej oraz powodowały transformacje układów koryt rzecznych (Vandenberghe 1993, 1995, Krzyszkowski 1995, 1996, Huisink 2000, van Huissteden, Kasse 2001, Zieliński, Goździk 2001, Starkel 2002, Starkel i in. 2007, Zieliński 2007). Efektem tej transformacji były zmiany parametrów hy- draulicznych rzek, takich jak głębokość i szerokość koryta, spadek oraz prędkość i moc strumienia. Dodatkowym czynnikiem, który w czasie zlodowacenia miał wpływ na transformację układów koryt rzecznych, były zmiany w sposobie ich zasilania. Zasilanie to mogło odbywać się wyłącznie za pośrednictwem wód roztopowych - reżim proglacjalny rzek (lodowcowy) lub wyłącznie rzek płynących z obszaru niezlodowaconego - reżim niwalny. Pośrednią pozycję zajmuje reżim pradolinny, w którym zasilanie rzeki (przepływu pradolinnego) odbywało się 
jednocześnie poprzez dopływy o reżimie niwalnym i proglacjalnym. Zmiany w zasilaniu rzek w rejonie Kotliny Toruńskiej były w czasie zlodowacenia wisły bezpośrednio uwarunkowane zasięgiem czoła lądolodu skandynawskiego (Weckwerth 2013, Weckwerth, Chabowski 2013).

Wydzielone w rejonie wschodniego odcinka Pradoliny Toruńsko-Eberswaldzkiej litotypy fluwialne opisują modele sedymentacji wysokoenergetycznych rzek meandrujących (litotyp M1) oraz czterech typów rzek roztokowych (litotypy B1-B4; por. Weckwerth 2013). Zmiany morfologii koryt rzek roztokowych funkcjonujących w rejonie Kotliny Toruńskiej w czasie środkowego vistulianu były uwarunkowane czynnikami allogenicznymi, które stymulowały zmiany parametrów hydraulicznych rzek (głębokość, spadek, kształt koryta, prędkość i moc przepływu), czego sedymentologicznym efektem były przeobrażenia form korytowych i dennych (por. Ashley 1990, Southard 1991). Dla roztok piaskodennych o odsypowym stylu sedymentacji wśród form korytowych przeważają proste odsypy poprzeczne, znane ze współczesnych oraz kopalnych środowisk sedymentacji fluwialnej (Cant, Walker 1978, Smith 1978, Miall 1985, Zieliński 1992, 1993, Bridge 1993, 2003). Koryta tego typu rzek mogą być również zdominowane przez złożone formy odsypów śródkorytowych (poprzecznych), których rozwój jest efektem łączenia się prostych odsypów foresetowych (Allen 1983, Bridge 1993, 2003). Transformacja morfologii piaskodennych koryt roztokowych (proste odsypy poprzeczne $\rightarrow$ odsypy złożone) może mieć charakter autogeniczny lub być rezultatem wpływu czynników zewnętrznych (Babiński 1992, Ashworth i in. 2000, 2011, Miall 2006, Sambrook Smith i in. 2006). Powyższe zmia-
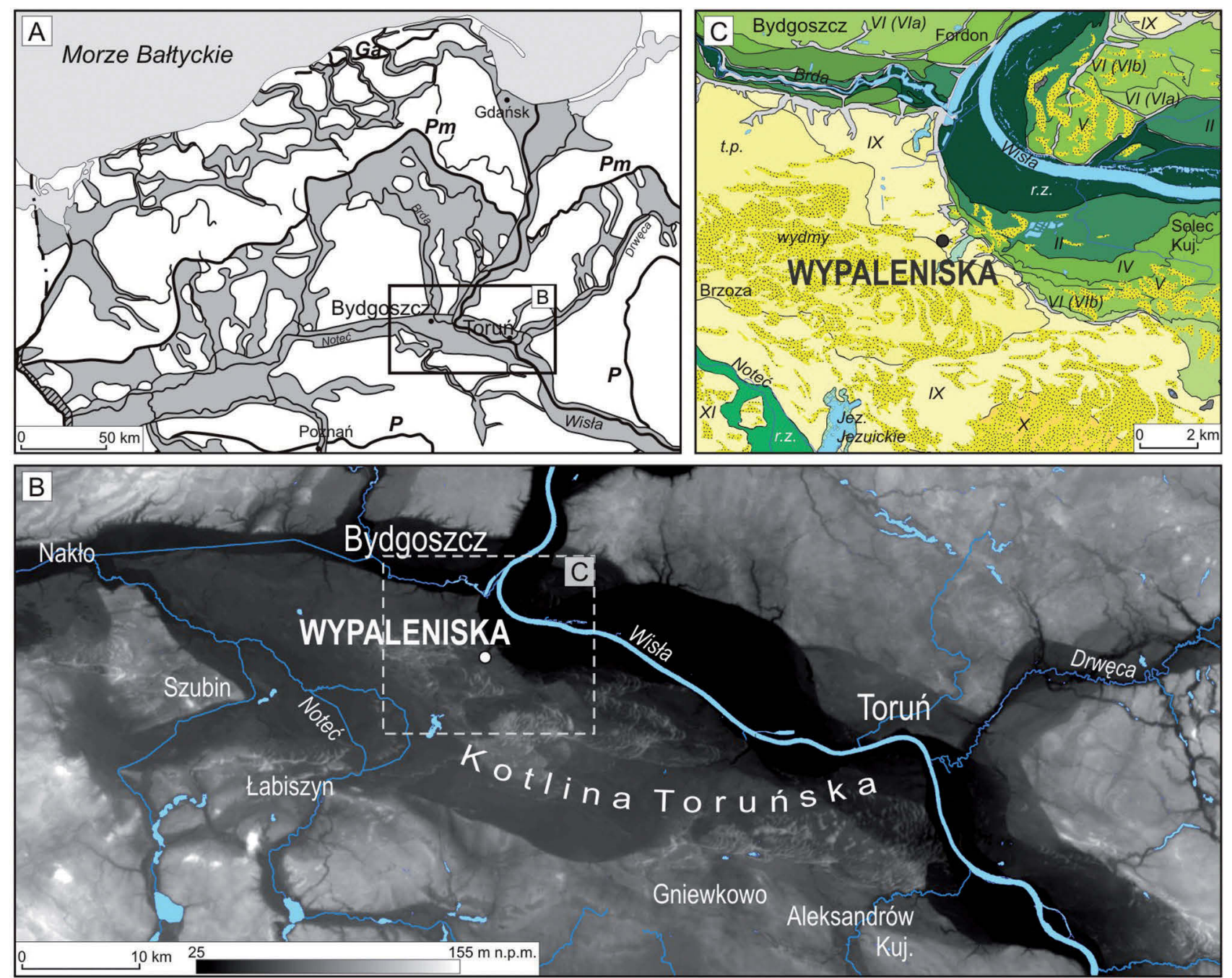

Ryc. 1. Lokalizacja stanowiska Wypaleniska

A - na tle zasięgów czoła lądolodu podczas zlodowacenia wisły według Kozarskiego (1995), fazy stadiału głównego zlodowacenia wisły: P - faza poznańska, Pm - faza pomorska, Ga - faza gardnieńska (kolor szary - zasięg sandrów, pradolin i dolin rzecznych); B - na tle ukształtowania powierzchni Kotliny Toruńskiej; C - w stosunku do zasięgu teras rzecznych i pradolinnych (r.z. - równina zalewowa, II-V - terasy rzeczne Wisły, VI-X - terasy pradolinne)

Fig. 1. Location of Wypaleniska site

A - against the extent of ice-sheet limits during Weichselian glaciation according to Kozarski (1995), phases of main stadial of Weichselian glaciation: P Poznań Phase, Pm - Pomeranian Phase, Ga - Gardno Phase (grey color - extent of outwash, pradolinas and river vallys); B - against the topography of the Torun Basin; $\mathrm{C}$ - in relation to the extent of river terraces and pradolina terraces (r.z. - floodplain, II-V - Vistula river terraces, VI-X - pradolina terraces) 
ny w morfologii i typie form korytowych piaskodennych rzek roztokowych są najlepiej zarejestrowane w osadach odsłaniających się w środkowej części Kotliny Toruńskiej na stanowisku Wypaleniska (ryc. 1). Aluwia te były deponowane na przełomie środkowego i późnego vistulianu, w czasie od około 30 do 21 tys. lat wstecz (Weckwerth i in. 2011, Weckwerth 2013).

\section{Metody badań}

Badania sedymentologiczne obejmowały identyfikację litofacji, analizę ich geometrii oraz orientacji i kontaktów pomiędzy litofacjami. Wydzielone zostały zespoły i kompleksy litofacjalne odpowiadające subśrodowiskom i środowiskom depozycyjnym osadów w obrębie wydzielonych jednostek sedymentacyjnych. Analizę litofacjalną przedstawiono w oparciu o kody litofacjalny i litogenetyczny (por. Zieliński 1992, 1995, 1998, Miall 2006, Zieliński, Pisarska-Jamroży 2012).

Analizy elementów kierunkowych dokonano na podstawie orientacji struktur prądowych warstwowań przekątnych. Wyznaczono parametry statystyczne: wektor wypadkowy VM, współczynnik ufności CI (przedstawiający wartość przedziału w stopniach, w którym zawiera się 95\% analizowanych pomiarów wokół wektora wypadkowego) oraz odchylenie standardowe SD (odnoszące się do wartości procentowej każdego z sektorów na diagramie rozetowym, podawane w procentach) i współczynnik zwartości R (Miall 1976, Davis 1986).

Analizę uziarnienia osadów mineralnych wykonano metodą sitową z wykorzystaniem sit o wymiarach oczek co 1 phi. Próbki osadów frakcji mułowych i iłowych poddane były analizie rozkładu uziarnienia wykonanej za pomocą laserowego analizatora wielkości ziaren Analysette 22 firmy Fritsch. Klasyfikację uziarnienia osadów przeprowadzono według skali zaproponowanej przez Uddena w modyfikacji Wentwortha (1922). Parametry statystyczne rozkładu uziarnienia zostały wyznaczone metodą momentów (Racinowski i in. 2001).

Wyniki analizy uziarnienia oraz analizy litofacjalnej posłużyły do rekonstrukcji parametrów hydraulicznych paleoprzepływów (rozmiarów makroform korytowych i form dennych, głębokości i prędkości paleoprzepływów oraz liczby Froude'a) według metodyki zaproponowanej przez Zielińskiego $(1992,1993)$ i Weckwertha (2011, 2013).

Badania składu minerałów ciężkich zostały przeprowadzone dla osadów piaszczystych o frakcji $0,1-0,25$ $\mathrm{mm}$. Minerały przeźroczyste oznaczono po separacji frakcji ciężkiej w roztworze poliwolframianu sodu o gęstości $2,9 \mathrm{~g} \mathrm{~cm}^{-3} \mathrm{i}$ w oparciu o ich cechy optyczne (por. Mange, Maurer 1992). Wydzielone zostały amfibole, pirokseny, biotyt, chloryty, epidoty, granaty, turmalin, cyrkon, rutyl, tytanit, dysten, staurolit, andaluzyt, sylimanit, apatyt, topaz, korund, glaukonit. Dla wymienionych grup minerałów wyznaczono wskaźnik mineralogiczny NR/R, który jest stosunkiem sumy minerałów nieodpornych na nisz- czenie fizyczne i chemiczne do sumy minerałów bardzo odpornych, odpornych i średnioodpornych (Racinowski 1995, 2000, Marcinkowski 2007, Marcinkowski, Mycielska-Dowgiałło 2013, Weckwerth, Chabowski 2013).

\section{Położenie i budowa geologiczna obszaru badań}

Obszar badań położony jest na południowy wschód od Bydgoszczy, w środkowej części Kotliny Toruńskiej (ryc. 1). Kotlina ta powstała w efekcie koncentrycznego napływu wód roztopowych i wód rzecznych, głównie w czasie fazy pomorskiej ostatniego zlodowacenia (ryc. 1A). Analizowane profile sedymentologiczne zlokalizowane są na terasie IX o wysokości 69 m n.p.m. (ryc. 1B, C). W kierunku północno-wschodnim terasa ta zakończona jest zboczem o maksymalnej wysokości 28 m, które kontaktuje się z niżej leżącymi powierzchniami teras II-VI (Weckwerth 2010).

W profilu osadów czwartorzędowych $\mathrm{w}$ rejonie stanowiska Wypaleniska na głębokości 39-21,5 m występują osady piaszczyste (ryc. 2), które mogą odpowiadać eemskiej i dolnovistuliańskiej formacji dolnego Powiśla (por. Makowska 1992, 2004). Powyżej, na głębokości 18-21,5 m, zalega warstwa iłów (formacja iłów chełmińskich), które były deponowane w jeziorze zastoiskowym w czasie stadiału świecia około 50-55 tys. lat temu (Wysota 2002, Weckwerth 2013). Osady ilaste przykrywa seria piaszczysta środkowego i późnego vistulianu. W jej skład wchodzą dwie formacje osadów rzecznych. Są to formacja

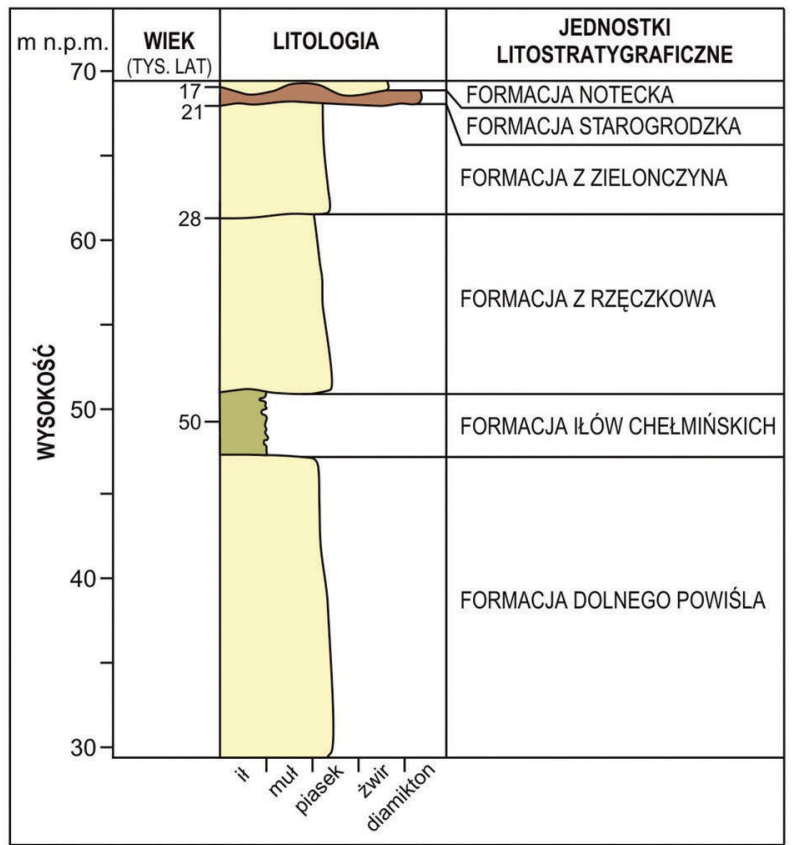

Ryc. 2. Profil litostratygraficzny osadów środkowego i późnego vistulianu w środkowej części Kotliny Toruńskiej

Fig. 2. Lithostratigraphic profile of Middle and Upper Weichselian in the central part of the Torun Basin 
z Rzęczkowa (Wysota 2002) pochodząca z okresu środkowego vistulianu (50-29 tys. lat) oraz formacja $z$ Zielonczyna (Weckwerth 2013), której aluwia były deponowane w czasie 28-21 tys. lat wstecz. Osady tych dwóch formacji na stanowisku Wypaleniska rozdziela rozległa powierzchnia erozyjna, zaś w zachodniej części Kotliny Toruńskiej warstwa gliny lodowcowej pochodzącej z okresu 28-30 tys. lat temu (Weckwerth 2013). Młodsza od niej glina lodowcowa (ze stadiału głównego zlodowacenia wisły, formacja starogrodzka wg Wysoty 2002, zalega na stanowisku Wypaleniska powyżej aluwiów formacji z Zielonczyna (ryc. 2). Jej miąższość jest tu zredukowana do $0,7 \mathrm{~m}$ w efekcie erozyjnej działalności wód płynących Pradoliną Toruńsko-Eberswaldzką pod koniec zlodowacenia wisły. Na stanowisku Wypaleniska osady pradolinne (formacja notecka wg Weckwertha 2013) mają miąższość do 0,3 m.

\section{Analiza sedymentologiczna osadów rzecznych}

Przedmiotem badań sedymentologicznych na stanowisku Wypaleniska była seria osadów rzecznych zalegająca pomiędzy osadami formacji iłów chełmińskich a warstwą gliny lodowcowej formacji starogrodzkiej (ryc. 2). Wśród widocznych $\mathrm{w}$ profilu Wypaleniska aluwiów o miąższości ponad $9 \mathrm{~m}$ zostały wyodrębnione dwie jednostki sedymentacyjne W1 i W2 (ryc. 3). Rozdziela je rozległa powierzchnia erozyjna $\mathrm{z}$ brukiem korytowym. Osady piaszczyste jednostki W1 korelowane są $\mathrm{z}$ formacją z Rzęczkowa, zaś piaski jednostki W2 należą do górnego ogniwa formacji z Zielonczyna.

\section{Jednostka W1}

Maksymalna miąższość osadów jednostki sedymentacyjnej W1 wynosi 2,3 m (ryc. 3). Tworzą ją zespoły litofacji $\mathrm{Sp}(\mathrm{SGp})$, które są zbudowane $\mathrm{z}$ umiarkowanie i dobrze wysortowanych piasków drobno- i średnioziarnistych z domieszką drobnych żwirów o warstwowaniu przekątnym płaskim średniej i wielkiej skali. Rozkłady uziarnienia tych osadów są w większości skośne ujemnie i leptokurtyczne, a wartość ich mediany waha się od $0,17 \mathrm{~mm}$ do $0,40 \mathrm{~mm}$. Laminy warstwowań przekątnych zapadają $\mathrm{w}$ kierunku zachodnim i północno-zachodnim $\left(261-345^{\circ}\right)$.

Wśród minerałów ciężkich występujących w aluwiach jednostki W1 zaznacza się ku jej stropowi zmniejszenie zawartości granatów od $50 \%$ do $15 \%$ oraz zwiększenie udziału amfiboli i biotytu (odpowiednio od 34 do 75\% i od 3 do 13\%) oraz piroksenów (od 1 do $6 \%$; ryc. 3 ).

Cechy litofacjalne aluwiów jednostki W1 wskazują na ich depozycję w korycie piaskodennej rzeki roztokowej, zdominowanym przez odsypy poprzeczne (FM-u), których osady tworzą zespoły litofacjalne $\mathrm{Sp}(\mathrm{SGp})$ (ryc. 3). Odsypy te miały charakter prostych (inicjalnych) form korytowych, których długość dochodziła do $55 \mathrm{~m}$. Pod względem wykształcenia litofacjalnego osady rzeczne tworzące jednostkę W1 odpowiadają litotypowi dystalnego koryta sandrowego (D-3 wg Zielińskiego 1992). Stwierdzona na stanowisku Wypaleniska dominacja osadów budujących pojedyncze odsypy poprzeczne oraz ich monotonna powierzchnia może wskazywać na rozwój tych makroform w obrębie głównego nurtu omijającego odsypy złożone (por. Sambrook Smith i in. 2006, Ashworth $i$ in. 2011). Przepływ wody w jego obrębie odbywał się $\mathrm{w}$ warunkach przejściowych pomiędzy dolną a górną częścią dolnego reżimu przepływu $($ Fr $0,25-0,35)$ z prędkością $0,9-1,3 \mathrm{~m} \mathrm{~s}^{-1}$, a jego średnia głębokość wynosiła około $1,4 \mathrm{~m}$.

\section{Jednostka W2}

Miąższość osadów jednostki sedymentacyjnej W2 dochodzi do $8,5 \mathrm{~m}$. Tworzą ją dwa zespoły litofacjalne $\mathrm{Sp}(\mathrm{Sr}, \mathrm{GSm})$ oraz $\mathrm{Sp}(\mathrm{Sr}, \mathrm{Se}, \mathrm{Sl})$ (ryc. 3). Spąg zespołu litofacjalnego $\mathrm{Sp}(\mathrm{Sr}, \mathrm{GSm})$ wyznacza warstwa bruku korytowego (litofacja GSm), w którym stwierdzono toczeńce diamiktonowe oraz ilaste. Mają one kształt kulisty, eliptyczny lub walcowy o dłuższej osi dochodzącej do $23 \mathrm{~cm}$. Powyżej litofacji GSm występują umiarkowanie i umiarkowanie dobrze wysortowane piaski drobnoi średnioziarniste o warstwowaniu przekątnym płaskim (Sp) średniej i wielkiej skali. Litofacje te wraz z piaskami drobnoziarnistymi o laminacji riplemarkowej $(\mathrm{Sr}, \mathrm{Src})$ tworzą trzy wielozestawy o łącznej miąższości do 2,0 m (ryc. 3). Azymuty upadu lamin warstwowań przekątnych wahają się od 197 do $333^{\circ}$.

Górną pozycję w obrębie jednostki W2 zajmuje zespół litofacjalny $\mathrm{Sp}(\mathrm{Sr}, \mathrm{Se}, \mathrm{Sl})$. W jego dolnej części znajdują się wielkoskalowe litofacje piasków drobnoziarnistych o warstwowaniu tabularnym (Sp). Lokalnie są one rozcięte do głębokości $0,5-0,7 \mathrm{~m}$ przez struktury wypełnień kanałowych (Se) bądź nadbudowane przez piaski o laminacji riplemarków wstępujących $(\mathrm{Src})$. W profilu Wypaleniska 2 litofacje Sp są nadbudowane przez zestaw małoi średnioskalowych litofacji o warstwowaniu tabularnym (Sp) lub małokątowym (Sl).

Wśród minerałów ciężkich dominują amfibole, których udział w dolnej i środkowej części jednostki W2 jest nieco większy (58-63\%) niż w części górnej (52-58\%) (ryc. 3). Ilość granatów jest zmienna i waha się od 21 do $31 \%$. Odsetek piroksenów i biotytu jest znacznie mniejszy i wynosi odpowiednio 5-6\% oraz 1-10\%.

Aluwia jednostki W2 były deponowane w korycie piaskodennej rzeki roztokowej. Ewolucja morfologii tego koryta przebiegała $\mathrm{w}$ dwóch etapach. Na początku pierwszego etapu doszło do erozji korytowej, która spowodowała usunięcie warstwy gliny lodowcowej oraz iłów zastoiskowych, najprawdopodobniej wskutek obniżenia poziomu bazy erozyjnej rzeki. W czasie późniejszej depozycji zespołu litofacjalnego $\mathrm{Sp}(\mathrm{Sr}, \mathrm{GSm})$ koryto roztokowe miało głębokość $0,8-1,8 \mathrm{~m}$ i było zdominowane przez proste odsypy poprzeczne o długości 30-50 m. Ich powierzchnię nadbudowywały riplemarki. 


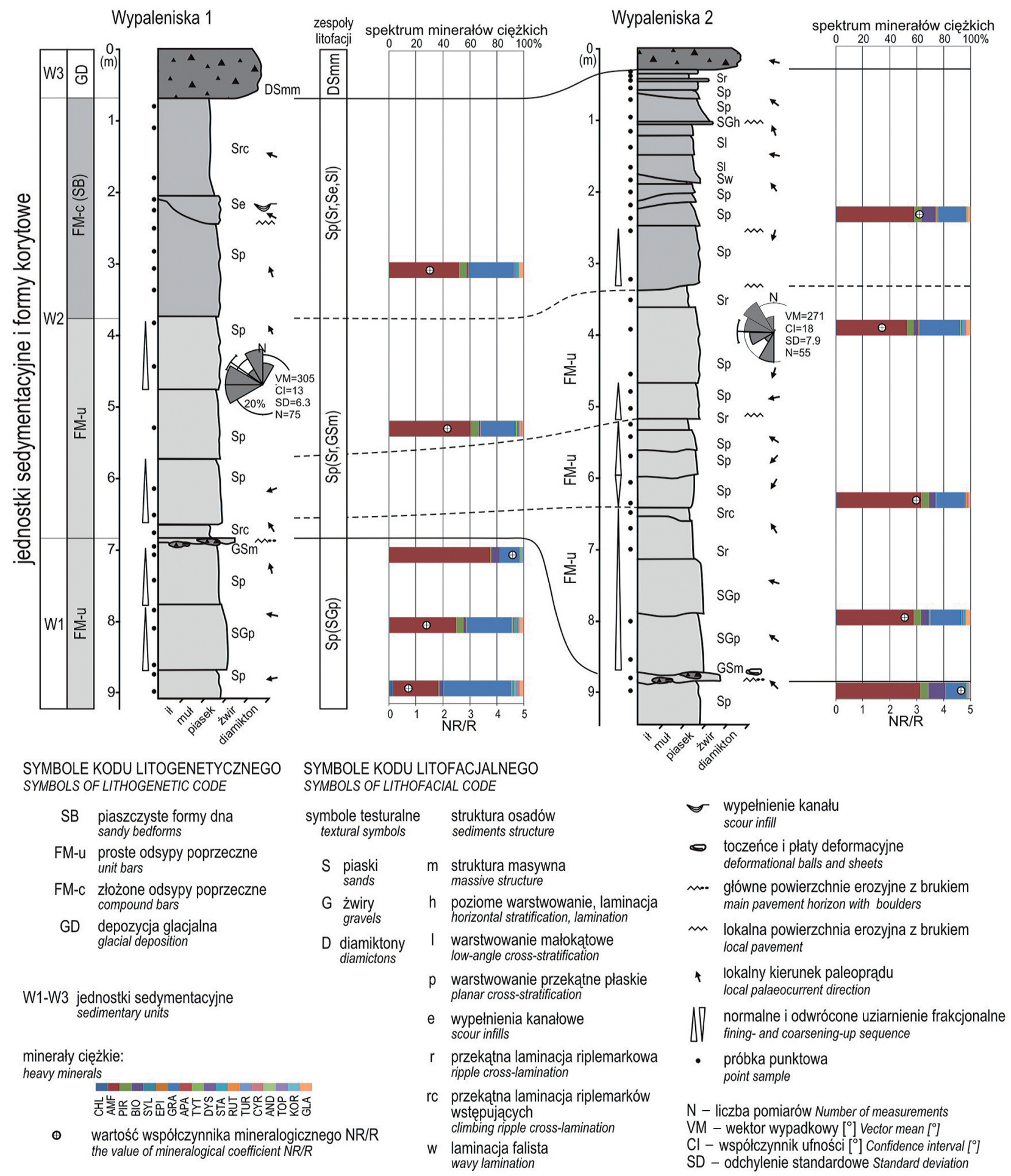

Ryc. 3. Profile litofacjalne na stanowisku Wypaleniska

Fig. 3. Lithofacial logs of the Wypaleniska site

W drugiej fazie ewolucji form korytowych doszło do łączenia się pojedynczych (inicjalnych) odsypów foresetowych, czego efektem był rozwój złożonych form śródkorytowych, tworzących płycizny śródkorytowe typu sand flats (por. Cant, Walker 1978). Reprezentują je zespoły litofacji $\mathrm{Sp}(\mathrm{Sr}, \mathrm{Se}, \mathrm{Sl})$, które były deponowane w korycie głębokim na ponad $2 \mathrm{~m}$. Długość odsypów złożonych była ponad dwukrotnie większa niż odsypów prostych. Powierzchnię odsypów złożonych, zalewaną podczas wezbrania, nadbudowywały diuny o prostych grzbietach i riplemarki. Była ona także rozcinana płytkimi rozmyciami kanałowymi. W czasie opadania wezbrania i spłycenia przepływu dwuwymiarowe diuny podlegały spłaszczeniu w warunkach przejściowych do górnego reżimu przepływu. W drugiej, dojrzałej fazie rozwoju koryta roztokowego prędkość płynącej wody wynosiła $1,2-1,3 \mathrm{~m} \mathrm{~s}^{-1}$. 


\section{Procesy transformacji form korytowych piaskodennych rzek roztokowych}

Transformacja układów korytowych rzek jest konsekwencją zmian warunków środowiskowych panujących w czasie funkcjonowania systemu rzecznego (Schumm 1977). Do głównych czynników, które powodowały i wyznaczały kierunki transformacji morfologii koryt rzecznych, należą zmiany klimatyczne, a także wahania poziomu bazy erozyjnej oraz ruchy neotektoniczne (Kozarski 1983, Rotnicki 1987, Vandenberghe i in. 1994, Kasse $\mathrm{i}$ in. 1995, Huisink 2000, van Huissteden, Kasse 2001, Busschers i in. 2005, 2007, 2011, Starkel i in. 2007). Następująca w efekcie zmian klimatycznych transformacja układów koryt była bezpośrednio konsekwencją zmian w rozwoju pokrywy wegetacyjnej, wielkości spłukiwania powierzchniowego, dostawy osadów do koryta rzecznego oraz sposobu jego zasilania. W przypadku Kotliny Toruńskiej zasilanie to było zależne od zasięgu czoła lądolodu i dopływu wód roztopowych (Weckwerth 2013, Weckwerth, Chabowski 2013). Przejawem transformacji rzeki były w tym przypadku zmiany parametrów hydraulicznych paleoprzepływów, takie jak głębokość i szerokość koryta, spadek oraz prędkość i moc strumienia.

Spośród wydzielonych na stanowisku Wypaleniska dwóch serii rzecznych tylko górna seria (jednostka W2) reprezentuje sukcesję aluwiów górnego ogniwa formacji z Zielonczyna, deponowaną w czasie 28-22 tys. lat temu, pomiędzy domniemanym, środkowovistuliańskim nasunięciem Zielonczyna a nasunięciem lądolodu skandynawskiego w fazie leszczyńskiej zlodowacenia wisły (ryc. 3, 4) (Weckwetrth 2013). Osady formacji z Zielonczyna były akumulowane w korycie rzeki roztokowej o piaszczystym dnie i zmiennej morfologii. Analiza sedymentologiczna aluwiów budujących dawne formy korytowe pozwoliła na wydzielenie dwóch ich faz rozwojowych. W pierwszej fazie depozycja korytowa zachodziła w rezultacie migracji prostych odsypów poprzecznych (osady dolnego członu jednostki W2, ryc. 3, litotyp B2 w formacji z Zielonczyna, ryc. 4). Formy te tworzyły się głównie w warunkach przejściowych pomiędzy dolną a górną częścią dolnego reżimu przepływu (Fr 0,3) (Weckwerth 2013). Ich powierzchnia lokalnie była nadbudowana w czasie wezbrania przez riplemarki lub niskie diuny o prostych grzbietach (Smith 1978, Miall 1985, Bridge 1993, 2003). Prędkość przepływu wody była zmienna i mogła wynosić maksymalnie do $1,3 \mathrm{~m} \mathrm{~s}^{-1}$. Jej największe wartości były charakterystyczne dla depozycji litofacji GSm reprezentujących żwirowo-piaszczyste pokrywy denne. Stwierdzona przewaga średnioi wielkoskalowych litofacji $\mathrm{Sp}$, powstających w efekcie migracji prostych odsypów foresetowych, oraz akcesoryczny udział litofacji Sr i Se upodabnia osady dolnego członu jednostki W2 do litotypu Platte River (Smith 1970, 1971) oraz odpowiada osadom dziewiątego typu rzeki roztokowej (wg Mialla (1985).

W drugiej fazie rozwoju form korytowych doszło do łączenia prostych odsypów foresetowych i utworzenia

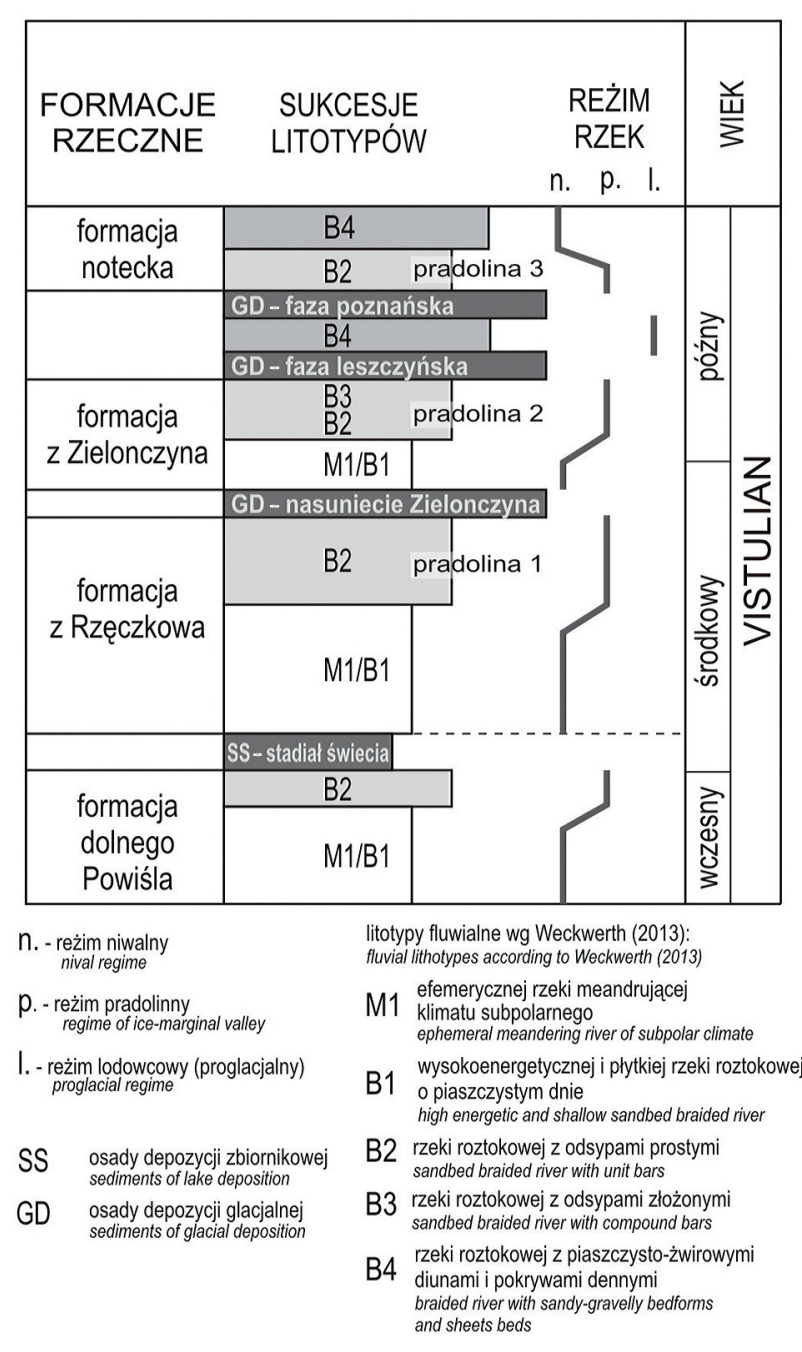

Ryc. 4. Sukcesje litotypów w formacjach fluwialnych oraz zmiany reżimu rzecznego w rejonie Kotliny Toruńskiej w czasie zlodowacenia wisły (Weckwerth 2013, zmienione)

Fig. 4. Successions of fluvial lithotypes in fluvial formations in the area of the Torun Basin during Weichselian glaciation (Weckwerth 2013, modified)

złożonych form śródkorytowych. W zapisie sedymentologicznym wyróżnia je obecność piaszczystych litofacji warstwowania tabularnego wielkiej i skrajnie wielkiej skali (miąższości ok. 2 m, profil Wypaleniska 1), nadbudowanych przez litofacje $\mathrm{Sr}, \mathrm{Se}, \mathrm{Sl}, \mathrm{Sp}$ (górny człon jednostki W2, ryc. 3, litotyp B3 w formacji z Zielonczyna, ryc. 4). Ich genezę łączyć należy z modelowaniem powierzchni makroform korytowych w czasie stanów powodziowych przez diuny lub w warunkach górnego płaskiego dna, które przechodziło w dno riplemarkowe. Podczas niższych stanów wody miało miejsce rozcinanie powierzchni i krawędzi odsypów złożonych przez płytkie kanały przelewowe (litofacje Se). Śródkorytowe odsypy złożone tworzyły w korycie piaskodennej roztoki rozległe płycizny środkorytowe (Cant, Walker 1978, Ashworth $\mathrm{i}$ in. 2000, 2011, Sambrook, Smith i in. 2006). Formy takie zostały opisane dla koryt Platte River (Blodgett, Stanley 1980, Crowley 1983), Wisły (Babiński 1992) i Jamuny (Best $\mathrm{i}$ in. 2003). W czasie rozwoju form złożonych odsypów poprzecznych przepływ korytowy odbywał się 
najczęściej w warunkach granicznych pomiędzy dolną a górną częścią dolnego reżimu przepływu, choć miejscami, w strefach koryt przelewowych lub płaskich rozmyć kulminacji odsypów, były to warunki przejściowe do przepływu rwącego lub nadkrytyczne (Fr 0,4-0,6).

Zrekonstruowane środowisko sedymentacji osadów odsypów złożonych na stanowisku Wypaleniska odpowiada warunkom rozwoju form korytowych South Saskatchewan River (Cant, Walker 1978). Nawiązuje ono także do warunków depozycji korytowej dziesiątego typu piaskodennej rzeki roztokowej w klasyfikacji Mialla (1985, 2006). Ponadto, ze względu na występowanie litofacji warstwowania tabularnego wielkiej skali, analizowane osady odsypów złożonych wykazują podobieństwo do litotypu D-3 wydzielonego dla sandrów Polski północno-wschodniej przez Zielińskiego (1993). Cechy litofacjalne pozwalają także zaliczyć analizowane osady do cyklu depozycyjnego $\mathrm{R}_{\mathrm{II}}$, który był według Wysoty $\mathrm{i}$ in. (1996) oraz Wysoty (2002) końcową fazą akumulacji formacji z Rzęczkowa.

Występowanie dwóch faz w rozwoju morfologii koryta roztokowego w czasie depozycji jednostki W2 znajduje potwierdzenie w wynikach analizy składu minerałów ciężkich. W obrębie zespołu litofacjalnego Sp(Sr,GSm) zaznacza się ku stropowi zmniejszenie udziału minerałów o niskich ekwiwalentach hydrodynamicznych, a wzrasta zawartość granatów. Maleją także wartości współczynnika NR/R od 2,9 do 1,7 (ryc. 3). W leżącym powyżej zespole litofacji $\mathrm{Sp}(\mathrm{Sr}, \mathrm{Se}, \mathrm{Sl})$ rośnie udział amfiboli (wraz ze wzrostem wskaźnika NR/R do 3,1), zaś maleje odsetek granatów, co jest charakterystyczne dla osadów glacifluwialnych (por. Racinowski 1995, 2000, Velbel 2007). Powyższe zmiany w składzie mineralnym aluwiów nawiązują do przekształceń architektury środowiska sedymentacyjnego koryta rzeki roztokowej o odsypowym stylu sedymentacji i mogły być efektem zmian w sposobie zasilania rzeki. Początkowo wysoka wartość wskaźnika mineralogicznego NR/R dla osadów budujących odsypy proste była związana $\mathrm{z}$ procesami erozji starszych osadów glacjalnych, których pozostałością są toczeńce gliniaste w warstwie bruku korytowego. Pod koniec sedymentacji tych odsypów wartość wskaźnika NR/R ustabilizowała się pomiędzy 1,7 a 2,2, co może wskazywać na niewielki udział w zasilaniu rzeki wód roztopowych i dominację zasilania niwalnego (Weckwerth 2013). Reakcją systemu rzecznego na zmiany w zasilaniu był rozwój złożonych odsypów śródkorytowych, powodując wzmożoną agradację korytową sprzyjającą awulsji nurtów piaskodennej roztoki (Miall 1994). Na wzrost udziału zasilania wodnolodowcowego w przepływie wskazuje zwiększenie się udziału wśród aluwiów odsypów złożonych minerałów ciężkich o małej odporności na abrazję mechaniczną. Przejawem tego jest wzrost wartości wskaźnika mineralogicznego NR/R dla jednostki W2 od 1,5 do 3,1 (ryc. 3). Poza zwiększeniem obciążenia rzeki rumowiskiem wynikającym z dopływu wód lodowcowych, akumulacji sprzyjał także niski spadek hydrauliczny (Weckwerth 2011, 2013).

\section{Wnioski}

Wyniki badań sedymentologicznych aluwiów zlodowacenia wisły odsłaniających się w północnej części Kotliny Toruńskiej, wraz z genetyczną interpretacją litofacji, rezultatami analizy petrograficznej i hydraulicznej paleoprzepływów, umożliwiły określenie zakresu i przyczyn zmian morfologii koryt rzek roztokowych.

1. Transformacja form korytowych piaskodennych rzek roztokowych obejmowała przeobrażenie prostych odsypów foresetowych w odsypy złożone tworzące rozległe płycizny śródkorytowe w okresie funkcjonowania pradolinnego systemu rzecznego.

2. Rozwój prostych odsypów poprzecznych dokonywał się głównie w efekcie zaprądowego przyrostu frontów progradacyjnych. Ich litofacjami wskaźnikowymi są piaski o warstwowaniu przekątnym płaskim średniej i wielkiej skali.

3. Powstanie odsypów złożonych należy wiązać z łączeniem odsypów prostych (pojedynczych) i nadbudowaniem ich powierzchni przez formy denne (głównie diuny i riplemarki). Do litofacji wskaźnikowych poprzecznych odsypów złożonych należą piaski o warstwowaniu przekątnym płaskim skrajnie wielkiej skali nadbudowane piaszczystymi litofacjami małej i średniej skali o warstwowaniu przekątnym płaskim.

4. Zmiana morfologii koryta rzeki roztokowej (odsypy proste odsypy złożone) następowała w wyniku włączenia się do systemu rzecznego cieków proglacjalnych, czego efektem było wzmożenie agradacji korytowej po zmianie zasilania (reżimu) niwalnego na pradolinny.

5. Istniejąca na przełomie środkowego i górnego vistulianu rzeka roztokowa, której osady odsłaniają się na stanowisku Wypaleniska, płynęła w kierunku zachodnim (ryc. 3). Poza zasilaniem wodami roztopowymi napływającymi z północy, uchodziły do niej również dopływy z południowego wschodu. Ich aluwia o wieku około 22 tys. lat wstecz odsłaniają się na stanowisku Raciążek (Molewski 2007). Powyższe dane wskazują na możliwość depozycji osadów jednostki W2, odpowiadającej górnemu ogniwu formacji z Zielonczyna, w obrębie pradoliny. Była to najprawdopodobniej druga $\mathrm{z}$ kolei tego typu forma, funkcjonująca krótko (ok. 1,5 tys. lat) przed nasunięciem czoła lądolodu w stadiale głównym zlodowacenia wisły w rejonie Kotliny Toruńskiej (ryc. 4). Trzecią pradoliną na obszarze badań w czasie vistulianu była Pradolina Toruńsko-Eberswaldzka.

\section{Literatura}

Allen J.R.L., 1983. Studies in fluvialite sedimentation: bars, bar complexes and sandstone sheets (low-sinuosity braided streams) in the Brownstones (L. Devonian), Welsh Borders. Sedimentary Geology 33: 237-293. 
Ashley G.M., 1990. Classification of large scale subaqueous bedforms: a new look at an old problem. Journal of Sedimentary Petrology 60: $160-172$.

Ashworth P.J., Best J.L., Roden J.E., Bristow C.S., Klaassen G.J., 2000. Morphological evolution and dynamics of a large, sand braid-bar, Jamuna River, Bangladesh. Sedimentology 47: 533-555.

Ashworth P.J., Sambrook Smith G.H., Best J.L., Bridge J.S., Lane S.N., Lunt I.A., Reesink A.J.H., Simpson C.J., Thomas R.E., 2011. Evolution and sedimentology of a channel fill in the sandy braided South Saskatchewan River and its comparison to the deposits of an adjacent compound bar. Sedimentology 58: 1860-1883.

Babiński Z. 1992. Współczesne procesy korytowe dolnej Wisły. Prace Geograficzne IGiPZ PAN 157.

Best J.L., Ashworth P.J., Bristow C.S., Roden J.E., 2003. Three-dimensional sedimentary architecture of a large, midchannel sand braid bar, Jamuna River, Bangladesh. Journal of Sedimentary Research 73: 516-530.

Blodgett K.H., Stanley K.O., 1980. Stratification, bedforms and discharge relations of the braided Platte River system, Nebraska. Journal of Sedimentary Petrology 50: 139-148.

Bridge J.S., 1993. The interaction between channel geometry, water flow, sediment transport and deposition in braided rivers. W: J.L. Best, C.S. Bristow (red.), Braided rivers. Geol. Soc. Spec. Publ. 75: 13-71.

Bridge J.S., 2003. Rivers and floodplains: forms, processes, and sedimentary record. Blackwell Publishing, Oxford.

Busschers F.S., Cohen K.M, Vandenberghe J., van Balen R.T, Kasse C., Wallinga J., Weerts H.J.T., 2011. Comment on 'Causes, consequences and chronology of large-magnitude palaeoflows in Middle and Late Pleistocene river systems of northwest Europe' by Westaway and Bridgland (2010). Earth Surface Processes and Landforms 36: 1836-1840.

Busschers F.S., Kasse C., van Balen R.T., Vandenberghe J., Cohen K.M., Weerts H.J.T., Wallinga J., Johns C., Cleveringa P., Bunnik F.P.M., 2007. Late Pleistocene evolution of the Rhine in the southern NorthSea Basin: imprints of climate change, sea-level oscillations and glacio-isostacy. Quaternary Science Review 26: 3216-3248.

Busschers F.S., Weerts H.J.T., Wallinga J., Kasse C., Cleveringa P., De Wolf H., Cohen K.M., 2005. Sedimentary architecture and optical dating of Middle and Late Pleistocene Rhine-Meuse deposits - fluvial response to climate change, sea-level fluctuation and glaciation. Netherland Journal of Geosciences 84: 25-41.

Cant D.J., Walker R.G., 1978. Fluvial processes and facies sequences in the sandy braided South Saskatchewan River, Canada. Sedimentology 25: 625-648.

Crowley K.D., 1983. Large scale bed configurations (macroforms), Platte River basin, Colorado and Nebraska: primary structures and formative processes. Geological Society America Bulletin 94: 117133.

Davis J.C., 1986. Statistic and Data Analysis in Geology. John Wiley, New York, Chichester, Brisbane, Toronto, Singapore.

Huisink M., 2000. Changing river styles in response to Weichselian climate changes in the Vecht valley, eastern Netherlands. Sedimentary Geology 133: 115-134.

Kasse C., Bohncke S., Vandenberghe J., 1995. Fluvial periglacial environments, climate and vegetation during the Middle Weichselian with special reference to the Hengelo Interstadial. Mededelingen Rijks Geologische Dienst 52: 387-413.

Kozarski S., 1983. River channel changes in the middle reach of the Warta valley, Great Poland lowland. Quaternary Studies in Poland 4: 159-169.

Kozarski S., 1995. Deglacjacja północno-zachodniej Polski: warunki środowiska i transformacje geosystemu ( 20ka 10ka BP). Dokumentacja Geograficzna 1.

Krzyszkowski D., 1995. An outline of the Pleistocene stratigraphy of the Kleszczów Graben (Bełchatów outcrop), central Poland. Quaternary Sciences Review 14: 61-83.

Krzyszkowski D., 1996. Climatic control on Quaternary fluvial sedimentation in the Kleszczów Graben, central Poland. Quaternary Sciences Review 15: 315-333.
Makowska A., 1992. Stratigraphy of the Younger Pleistocene in the Dolne Powiśle and the Elbląg Elevation based on mapping and boreholes. Geological Quarterly 36: 97-120.

Makowska A., 2004. Najpełniejszy w Polsce kompleks młodoplejstoceński (eem i vistulian) na dolnym Powiślu i Wzniesieniu Elbląskim. Przegląd Geologiczny 52(9): 887-894.

Mange M.A., Maurer H.F.W., 1992. Heavy minerals in colour. Chapman and Hall, London.

Marcinkowski B., Mycielska-Dowgiałło E., 2013. Heavy-mineral analysis in Polish investigations of Quaternary deposits: a review. Geologos 19: 5-23.

Marcinkowski B., 2007. Wykorzystanie składu mineralnego i morfologii ziaren minerałów ciężkich do określania środowiska sedymentacyjnego. Przegląd Geologiczny 55(3): 207.

Miall A.D., 1976. Palaeocurrent and palaeohydrologic analysis of some vertical profiles through a Cretaceous braided stream deposit, Banks Island, Arctic Canada. Sedimentology 23: 459-483.

Miall A.D., 1985. Architectural-Element Analysis: a new method of facies analysis applied to fluvial deposits. Earth-Science Reviews 22: 261-308.

Miall A.D., 1994. Reconstructing fluvial macroform architecture from two-dimensional outcrops; examples from the Castlegate Sandstone, Book Cliffs, Utah. Journal of Sedimentary Research 64: 146-158.

Miall A.D., 2006. The geology of fluvial deposits. Sedimentary facies, basin analysis, and petroleum geology. Springer, Berlin, Heidelberg, New York.

Molewski P., 2007. Neotektoniczne i glacidynamiczne uwarunkowania wykształcenia plejstocenu Wysoczyzny Kujawskiej. Wydawnictwo Naukowe UMK, Toruń.

Racinowski R., 1995. Analiza minerałów cieżkich w badaniach osadów czwartorzędowych Polski. W: E. Mycielska-Dowgiałło, J. Rutkowski (red.), Badania osadów czwartorzędowych. Wybrane metody i interpretacja wyników. WGiSR UW, Warszawa: 151-166.

Racinowski R., 2000. Niektóre problemy interpretacji wyników analiz minerałów ciężkich w badaniach osadów czwartorzędowych. Przegląd Geologiczny 48(4): 354-359.

Racinowski R., Szczypek T., Wach J., 2001. Prezentacja i interpretacja wyników badań uziarnienia osadów czwartorzędowych. Wydawnictwo UŚ, Katowice.

Rotnicki K., 1987. Main phases of erosion and accumulation in the middle and lower Prosna valley in the Last Glacial-Interglacial Phase. Quaternary Studies in Poland 9: 73-83.

Sambrook Smith G.H., Ashworth P.J., Best J.L., Woodward J., Simpson C.J., 2006. The sedimentology and alluvial architecture of the sandy braided South Saskatchewan River, Canada. Sedimentology 53: 413-434.

Schumm S.A., 1977. The fluvial system. John Wiley \& Sons, New York-London-Sydney Toronto.

Smith N.D., 1970. The braided stream depositional environment: comparison of the Platte River with some Silurian clastic rocks, north central Appalachians. Geological Society of America Bulletin 81: 2993-3014.

Smith N.D., 1971. Transverse bars and braiding in the lower Platte River, Nebraska. Geological Society of America Bulletin 82: 3407-3420.

Smith N.D., 1978. Some comments on terminology for bars in shallow rivers. W: A.D. Miall (red.), Fluvial Sedimentology, Canadian Society of Petroleum Geology, Memoir 5: 85-88.

Southard J.B., 1991. Experimental determination of bedform stability. Annual Review of Earth and Planetary Sciences 19: 423-455.

Starkel L., 2002. Younger Dryas-Preboreal transition documented in the fluvial environment of Polish rivers. Global and Planetary Changes 35: 157-167.

Starkel L., Gębica P., Superson J., 2007. Last Glacial-Interglacial cycle in the evolution of river valleys in southern and central Poland. Quaternary Sciences Review 26: 2924-2936.

van Huissteden J., Kasse C., 2001. Detection of rapid climate change in Last Glacial fluvial successions in The Netherlands. Global and Planetary Change 28: 319-339.

Vandenberghe J., 1993. Changing fluvial processes under changing periglacial conditions. Zeitsrift für Geomorphologie (Supplement) 88: $17-28$. 
Vandenberghe J., 1995. Timescales, climate and river development. Quaternary Sciences Review 14: 631-638.

Vandenberghe J., Kasse C., Bohncke S.J.P., Kozarski S., 1994. Climate-related river activity at the Weichselian-Holocene transition: a comparative study of the Warta and Maas rivers. Terra Nova 6: 476-485.

Velbel M.A., 2007. Surface textures and dissolution processes of heavy minerals in the sedimentary cycle: examples from pyroxenes and amphiboles. W: M.A. Mange, D.T. Wright (red.), Heavy Minerals in Use. Developments in Sedimentology Series 58: 215-245.

Weckwerth P., 2010. Evolution of the Torun Basin in the Late Weichselian. Landform Analysis 14: 57-84.

Weckwerth P., 2011. Palaeoslopes of Weichselian sand-bed braided rivers in the Torun Basin (Poland): results of palaeohydraulic analysis. Geologos 17: 227-238.

Weckwerth P., 2013. Ewolucja fluwialnych systemów depozycyjnych i jej uwarunkowania paleogeograficzne w Kotlinie Toruńskiej podczas zlodowacenia wisły. Wydawnictwo Naukowe UMK, Torun.

Weckwerth P., Chabowski M., 2013. Heavy minerals as a tool to reconstruct river activity during the Weichselian glaciation (Torun Basin, Poland). Geologos 19: 25-46.

Weckwerth P., Przegiętka K., Chruścińska A., Woronko B., Oczkowski H.L., 2011. Age and sedimentological features of fluvial series in the Torun Basin and the Drwęca Valley (Poland). Geochronometria 38: 397-412.

Wentworth C.K., 1922. A scale of grade and class terms for clastic sediments. Journal of Geology 30: 377-392.
Wysota W., 2002. Stratygrafia i środowiska sedymentacji zlodowacenia wisły w południowej części dolnego Powiśla. Wydawnictwo Naukowe UMK, Torun.

Wysota W., Lankauf K.R., Molewski P., Szmańda J., 1996. Sedymentologia interstadialnej serii rzecznej (Rzęczkowo) zlodowacenia wisły (vistulian) odsłoniętej w SW krawędzi Wysoczyzny Chełmińskiej. AUNC, Geografia 28: 39-63.

Zieliński T., 1992. Proglacial valley facies of the Silesian Upland - genetic factors and their sedimentological effects. Geologia Sudetica 26: 83-118.

Zieliński T., 1993. Sandry Polski północno-wschodniej - osady i warunki sedymentacji. Prace Nauk. UŚ 1398.

Zieliński T., 1995. Kod litofacjalny i litogenetyczny - konstrukcja i zastosowanie. W: E. Mycielska-Dowgiałło, J. Rutkowski (red.), Badania osadów czwartorzędowych. Wybrane metody i interpretacja wyników. WGiSR UW, Warszawa: 221-234.

Zieliński T., 1998. Litofacjalna identyfikacja osadów rzecznych. W: E. Mycielska-Dowgiałło (red.), Struktury sedymentacyjne i postsedymentacyjne w osadach czwartorzędowych i ich wartość interpretacyjna, Warszawa: 195-257.

Zieliński T., 2007. The pleistocene climate-controlled fluvial sedimentary record in the Bełchatów mine (central Poland). Sedimentary Geology 193: 203-209.

Zieliński T., Goździk J., 2001. Palaeoenvironmental interpretation of a Pleistocene alluvial succession in central Poland: sedimentary facies analysis as a tool for palaeoclimatic inferences. Boreas 30: 240-253.

Zieliński T., Pisarska-Jamroży M., 2012. Jakie cechy litologiczne warto kodować, a jakie nie? Przegląd Geologiczny 60(7): 387-397. 